\title{
Determinants of South Africa's Orange Trade Flows in the Top European and Asian Importing Countries
}

\author{
Luyolo Matolo ${ }^{1}$, Li Zhemin ${ }^{1}$, Yu Wen ${ }^{1} \&$ Huang Min $^{1}$ \\ ${ }^{1}$ Agricultural Information Institute, Chinese Academy of Agricultural Sciences, Beijing, China \\ Correspondence: Li Zhemin, Agricultural Information Institute, Chinese Academy of Agricultural Sciences No. \\ 12, Zhongguancun South Street, Beijing 100081, China. Tel: 86-152-1011-6489. E-mail: lizhemin@caas.cn
}

Received: February 12, 2016 Accepted: May 9, 2016 Online Published: June 15, 2016

doi:10.5539/jas.v8n7p38 URL: http://dx.doi.org/10.5539/jas.v8n7p38

\begin{abstract}
South Africa orange exporters have for a long time enjoyed a sizeable market share in many parts of the world. A large portion of that sizeable market share can be located in the European countries then followed by fast developing countries in Asia. This market share can be associated with a declining South African currency compared to the values of these major currencies. On the other hand a number of trade agreements that have been reached by South Africa and these countries over the years have also contributed handsomely in the mentioned market share. Furthermore, diets of consumers in these countries have as well contributed in the conquered market share. Although a number of studies have been conducted on the subject of South Africa's declining currency and the established trade agreements on products with mixed magnitudes in influencing trade flows, further research is needed for a better understanding on the trade determinants patterns in specific products. This paper focuses on the determinants of South Africa's orange trade in the top European and Asian importing countries. In order to understand these trade determinants, gravity model has been applied to identify and analyze significant factors encouraging or discouraging the quantities/volumes of oranges exported to the above mentioned countries. Findings have shown that over the reviewed period, South Africa's orange exports to the European market have been consistence, while exports to Asian market started slow and gradually increased over the years. Gravity model estimated coefficients also showed expected signs.
\end{abstract}

Keywords: Asian market, European market, gravity model, South Africa orange exports, trade determinants

\section{Introduction}

In South Africa (SA), when orange plantations were introduced decades and decades ago the main aim was exportation. Oranges are part of the four citrus broad categories which also include grapefruit, lemons and limes and soft citrus. The above mentioned citrus categories are exported to more than sixty foreign countries. The SA citrus industry has a long and successful history of growth, innovation and forward thinking and as a result it has been very competent in the international markets. Since year 2006, South Africa has been the second largest exporter of fresh citrus in the world, although it is only the twelfth largest producer. Citrus industry in South Africa is among the leading horticultural industry sitting at position number three after vegetables and the deciduous fruit industry in terms of gross value. Of the about 2 million tons of citrus produced in Southern Africa every year, around $69 \%$ is exported, $7 \%$ is processed, and the remaining $24 \%$ is sold on the local market. The large volumes of exports validate the common knowledge that being export orientated for producers and exporters have to do with much money from foreign currency. Oranges constitute $70 \%$ of total citrus export output (Ntombela \& Moobi, 2013; Kapuya et al., 2015). South Africa is found in the leading countries in orange exports, with over half of its exports destined for the European countries with Russia included. Such large quantities can be associated with trade agreements which have been established between SA and European countries over the years. One of the trade agreements established by SA and EU is a bilateral Free Trade Agreement (FTA) called the Trade, Development and Cooperation Agreement (TDCA), whose architecture is premised on the EU granting the country much more access in terms of the tariff regime (DAFF, 2013). In terms of the TDCA, South Africa has duty-free access to the European market for about $65 \%$ of its agricultural products. Asian market on the other hand has been becoming a new market destination of interest for SA orange exports and that has been sealed by a number of recently established trade agreements. SA orange exporters currently exports under most favored nation (MFN) clause which entails huge tariff cuts. According Baldwin \& 
Murray to (1977), MFN tariff cuts have seemed to hold the prospect of an adverse effect on the beneficiary nations by eroding the margins of the preference established under generalized system of preferences. The above statement has been but a different case for SA orange exporters to the studied markets in this paper whereby tariff cuts have been to zero percent and such significant cuts haves seen large increases in SA orange exports especially to the Asian market. On the other hand an ever increasing habit of eating healthy better known from the developed countries has swept-inn in the people of the developing countries which make the consumption of fruits like oranges also increase. This phenomenon is having major impact in most Asian countries where food systems are changing, resulting in greater availability and diversity of food due to urbanization, increasing incomes, market liberalization and foreign direct investment (Haddad, 2003; Popkin, 1993; Reardon et al., 2003). For example not a long time ago countries like China and India focused on finding ways to feed a large population with limited recourses, but recently, that focus has shifted to be more on feeding people healthy and safe goods (Maru, 2014; DAFF, 2013). The above mentioned trade determinants with positive influence in encouraging large quantities of citrus-oranges being exported to this lucrative markets have been gradually over shadowed by non tariff measures (NTMs) which have been proliferating the developed countries in the name of protecting human health, plant protection, animal health and environment. Most developing countries, South Africa being one them face great difficulties in meeting the standards for exporting agricultural products to developed countries due to less or no capacity to posses the modern equipments for meeting the set requirements. It is worth to note in developing countries such measures lead to the liquidation of many farmers, the disappearance of smaller exporters. However the NTMs are not the main focus of this paper and therefore are not analyzed and that requires a further research beyond this paper.

It is in this regard that this paper evaluates the SA orange trade determinants to the top European and Asian importing countries by identifying and analyzing significant factors that have encouraged or discouraged the quantities/volumes of citrus exported based on a gravity model and time series data from 2001 to 2013, prior the rise of NTMs in these countries. To put the analysis into context, the paper first explores SA orange export trends to the various regions of the world and then move to explore SA orange export trends to the top selected importing countries in Europe and Asia. This is followed by methodology applied and data materials. Furthermore the paper presents results and discussions and lastly conclusion remarks.

\subsection{SA Orange Export Trends to the Various Regions of the World}

Figure 1 below presents the exports of SA oranges to the various regions of the world over the period of 13 years reviewed in this paper. Over 12 million tons of oranges worth billions of US Dollars were exported during this period. In all that period most of exports went to the European and Asian market. In the year 2013 alone, exports to Europe accounted for $53 \%$ of all exported oranges to the various regions of the world, and Asia followed with an account of $36 \%$. The top most importing countries of SA oranges are located in these two markets, Europe and Asia. The Americas and Africa also constitute important markets for SA exports of oranges. South Africa's orange exports to the European market have been consistence over the past decade, remaining over 400 thousand tons on a yearly basis. On the other hand, exports to Asian market did remarkable when overtook those exports to European market in the year 2005 (above 600 thousand tons to Asia compared with slightly above 500 thousand tons to Europe) and 2006 (above 500 thousand tons to Asia compared with just above 500 thousand tons to Europe) before retreating again in 2007. The exponential increase of orange exports to the Asian market in these 2 mentioned years was due to the adjustment of sanitary and phytosanitary measures in the European market on developing country exports of agricultural and food products. In the other years, exports to European market have just been stable as mentioned before. 


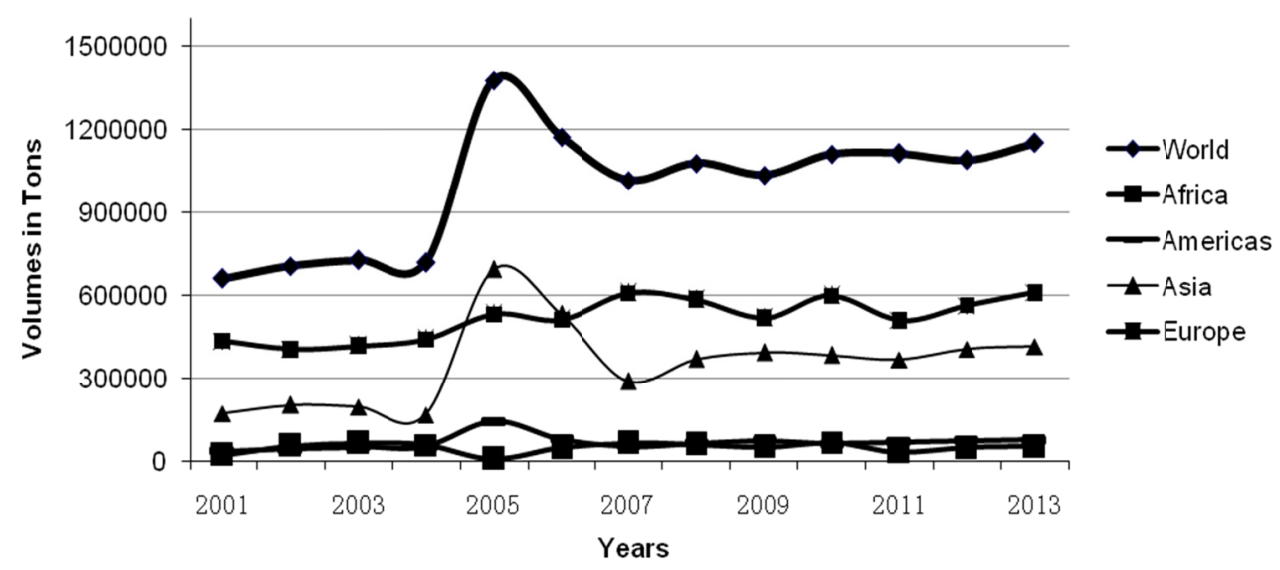

Figure 1. Volumes of oranges exported to various regions (2001-2013)

Source: Own calculations based on data from DAFF (2015).

\subsection{SA Orange Export Trends to the Top Selected Importing Countries (European and Asian Markets)}

European and Asian markets presented in Figure 2 bellow are made up of the top importing countries in these markets. For the selected countries it is important to note that only those countries in whose orange imports from South Africa were at least 10000 tons in at least one year during the period under review are presented in Figure 2. Due to their relative importance to exports of South African oranges, these markets are further analysed.

In the European market, large quantities of SA orange exports go to the European Union (EU) countries. For intance in year 2013 alone, $76 \%$ of all SA orange exports to Europe were absorbed by the European Union countries. The EU was followed by Eastern Europe at 23\% while the remaining 1\% went to Northern, Southern and Western Europe. Exports to European market peaked at 591020 tons in year 2007. Such peak which was relealised in year 2007 can be associated with quality of fruits during that year and that means most of the fruits presented for exports met the set standards to enter Europian market. However, there were some years for instance in years 2001 to 2004 and in years 2009 and 2011 where there were fewer exports. The primary cause of such fewer exports may have been due to less quantity of citrus exported, owing to floods especially in year 2001, which affected the quality and the size of the crop while on the other hand may have been non-tariffs measures which are standing tall in the European market. To further bring to light the plight of non tarff measures which has suffered SA oranges in entering the Europian market was the case of four consignments that were reported to contain the citrus black spot (CBS) disease. It is important to note that CBS is not harmful to human health even though it may appear unattractive on the surface of the fruit's skin. Almost $15 \%$ of exports which were destined to European market had to be diverted to other less stringent markets and that left SA orange industry at a loss of an estimated above 59 million US Dollars. 


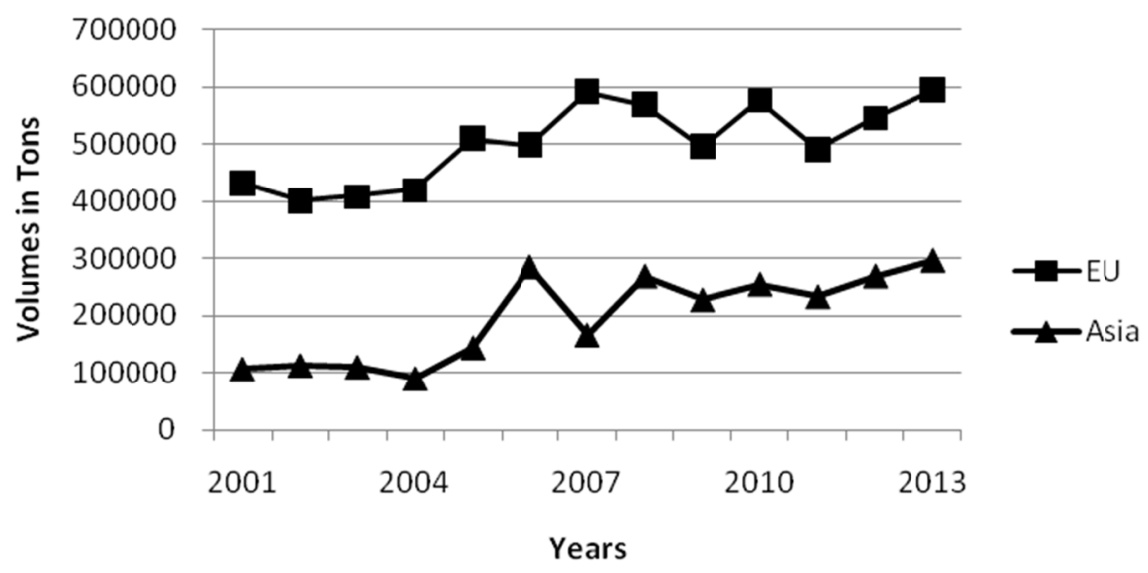

Figure 2. Volumes of oranges exported to top importing countries in Europe and Asia

Source: Own calculations based on data from DAFF (2015).

The Asian market is made up of fast developing countries. It is of high importance to mention once again, that the ever increasing habit of eating healthy which has been the boiling topic among the developed countries have swept-inn in the people of the developing countries such as Middle East and Far East countries in Asia. This phenomenon is having major impact in most Asian countries where food systems are changing, resulting in greater availability and diversity of food due to urbanization, increasing incomes, market liberalization and foreign direct investment (Haddad, 2003; Popkin, 1993; Reardon et al., 2003). Consumption of fruits like oranges has seen rather a rapid increase resulting high demand for imports in these countries. Over the reviewed period in this paper, Asian market has been steadily increasing its orange imports from South Africa, validating the argument of changing trends in consumption by the developing countries. Looking closely at Figure 2 presented above, Asian market did extremely well in year 2005 when it overtook the European market in orange imports (above 600 thousand tons compared with slightly above 500 thousand tons to Europe) and in year 2006 (above 500 thousand tons to Asia compared with just above 500 thousand tons to Europe) before retreating again in 2007 .

\section{Methodology and Data Materials}

\subsection{Methodology}

Methods of analysis adopted in this paper vary from descriptive statistics to inferential statistics in a form of model application for data analysis. The use of descriptive statistics is in line with the application that has been applied for over a number of years in many studied fields. It is widely known for providing concise summaries about the sample and about the observations that have been made. This statement above is visible in the analysis provided in Figures 1 and 2. The summaries made in analysis from the above figures form the basis of the initial descriptions of the data which are part of more extensive statistical analysis (Manju et al., 2014).

In addition to further understand the underlying factors that may have influenced the export trends which have been presented in Figure 2, gravity model has been adopted to provide a detailed analysis. The model was introduced by Sir Isaac Newton over 50 years ago and it applies Newton's universal law of gravitation in physics.

For many years the same model has been used in social sciences for explaining many streams of movement, such as migration, commuting and tourism (Bergstrand, 1985; Buch et al., 2004). In economics, it was first introduced by Tinbergen when he applied it for analysis in international trade (Tinbergen, 1962). Due to its success at the time in explaining trade determinants, Pöynöhen followed and applied the same model in the study he published in 1963 titled "A Tentative Model for the Volume of Trade between Countries". Since its adoption to empirical economics in explaining bilateral trade, this model has proven to be a great tool to date and it has been consistent with several theoretical models of trade (Feenstra et al., 2001). In study conducted by Kristjánsdóttir in the year 2008, gravity model proved to be an effective tool in explaining bilateral trade flows by clearly explaining the factors that aid or restrict trade among trading countries. There have been some differences among economists about the trade-theoretical foundation of the model. Regardless of such differences, gravity model has 
surprisingly proven itself to be robust in empirical relationship which prevailed in spite of changing focus in trade theory (Melchior et al., 2009).

The basic form of the gravity equation is presented below:

$$
F_{i j}=G\left(M_{i \beta 1} M_{j \beta 2} / D_{i j}^{\beta 3}\right) \varepsilon_{i}
$$

In the above equation, $F_{i j}$ represents volume of trade from country $i$ to country $j, M_{i}$ and $M_{j}$ usually represent the GDPs for countries $i$ and $j, D_{i j}$ represents the distance between the two trading countries, and $\varepsilon_{i j}$ represents an error term with expectation equal to 1 . It is worth to note that in different circumstances some theoretical approaches allow gravity model to be rationalized in different spheres. Take for instance the case of total supply and demand of the exported or imported goods tend to increase with country size. The location of the trading countries adds another important feature since GDP levels may depend on geographic economic placement and distance. Therefore a step worth to be incorporated in developing theoretical approach to gravity model is the one mentioned in the previously which to date has been done only to a limited extent (Melchior et al., 2009).

Distance parameter as a proxy for various trade costs variables normally has negative estimates though the absolute value of the distance parameter could be reduced. In essence, the distance parameter could be of no significance if it was possible to measure all factors that influence trade correctly. GDP levels may depends on geographic location of the trading partners, for example countries located centrally have higher GDP levels due to location placement. Therefore GDP may be endogenous and somehow depend indirectly on distance. One of the counterattacks proposed measure to such biasness by Anderson and Wincoop, is a term in the gravity equation that captures geographic location of the countries involved in trade with each other to be included. Again the proposed measure can be taken into account if estimation in the gravity equation is with multilateral data for many countries.

This paper follows Melchior et al. (2009) by adding tariff term to the gravity equation and further add exchange rate term then the equation changes to:

$$
\ln \left(E X P_{k j t}\right)=\alpha+\beta 1 \ln \left(G D P_{j t}\right)+\beta 2 \ln \left(D_{j t}\right)+\beta 3 \ln \left(G D P P C_{j t}\right)+\beta 4 \ln \left(E X_{k j t}\right)+\beta 5 \ln \left(T_{k j t}\right)+\varepsilon_{j t}
$$

Since the focus of this paper is on South Africa's orange exports only, therefore the $i$ subscript has been dropped due to commonality in all observations, but subscript $\mathrm{k}$ representing oranges has been added. The table below presents the variables that are used in the above gravity equation.

Table 1. Variables used in the modified gravity equation

\begin{tabular}{ll}
\hline Variables & Explanation \\
\hline $\ln (E X P)$ & Logarithm of Volumes of exported oranges in year t \\
$\ln (G D P)$ & Logarithm of GDP of the importing countries expressed in US\$ in the year $\mathrm{t}$ \\
$\ln (G D P P C)$ & Logarithm of GDP per capita in year $\mathrm{t}$ \\
$\ln (D)$ & Logarithm of Distance from the capital city of South Africa to the capital cities of the importing countries \\
$\ln (E X)$ & Logarithm of Real exchange rate between South Africa and the importing countries in year $\mathrm{t}$ \\
$\ln (T)$ & Logarithm of Total ad valorem tariffs levied on South African oranges exported to the importing countries in year $\mathrm{t}$ \\
$\varepsilon$ & The error term \\
$\mathrm{k}$ & Oranges \\
$\mathrm{j}$ & Importing countries \\
$\mathrm{t}$ & Time when exports took place expressed on an annual basis \\
\hline
\end{tabular}

\subsection{Data Materials}

Data materials used in this paper contains annual orange exports from South Africa to the top importing countries in Europe and Asia, GDPs, population, total ad valorem tariffs levied on South African citrus when exported to the these countries during the year of export, average annual exchange rate and distance from the capital city of South Africa to the capital cities of the studied counties. The construction of the mentioned data collection is based on the following years 2001-2013. The main sources of data materials are the following: Orange exports are taken from department of agriculture, fisheries and forestry (DAFF) South Africa and Easy Data by Quantec South Africa. European and Asian countries data being studies such as GDPs, GDP per capita and Population are taken from the World Bank's WDI (World Development Indicators), online version 2014. Data of geographical distance are constructed from coordinates taken from the Global Cities database. Tariff 
data are taken from UNCTAD's TRAINS database, also using WITS. Exchange rates data are own calculations and are obtained through the following steps:

$>$ The nominal exchange rate is calculated as the annual average of the national currency unit of South Africa per US dollar.

$>$ Data of exchange rate for both trade partners are obtained from the World Bank.

\section{Results and Discussion}

The following regression Tables 2 and 3 present results of the SA orange top importing countries in Europe and Asia. As mentioned in the abstract that this paper seeks to understand by identifying and analyzing significant factors encouraging or discouraging the quantities/volumes of oranges exported to the above mentioned markets using the gravity model and time series data from year 2001 to 2013. Even though there has been a detection of deterioration in the fit of the gravity equation used, the estimated parameters are general still significant and the model can be used for reliable results.

\subsection{Analysis of SA Orange Exports to Top Importing European Countries}

The orange export determinants being analyzed are economic size, and distance between the two countries, tariffs expressed in ad-valorem tariffs, the real exchange rate volatility and the estimated coefficients seem to have expected signs. A $1 \%$ increase in the GDP of these reviewed countries tends to be associated with a $2.4 \%$ increase in the volumes of oranges being exported and this estimate is statistically significant. The distance as proxy for transportation costs has an element of discouraging the desired large volumes of exports by SA orange exporters at $3 \%$. The real exchange rate is highly significant correlation with trade variation indicating that price competitiveness is important for South Africa's orange exports, when South African currency appreciates with a percent tends to be associated with $8 \%$ percent fall of volumes being exported. The inclusion of GDP per capita in a $\log$ form as an export determinant in this paper is in line with the study conducted by Maurseth (2003) whereby it was noticed that tariffs and income levels are correlated so to overcome the possibility of an omitted variable bias the income level was taken into account. A $1 \%$ increase in the income levels tends to be associated with $1.1 \%$ increase exports from SA. European market has been for a long time a prioritized market destination for SA oranges due to its conducive importing standards that have been established after certain trade agreements been reached. One of the trade determinants which has been discouraging trade for decades such as tariffs have been reduced up to zero percent as of year 2005. It of no surprise to experience a positive sign in the parameter estimates for tariffs on the presented results in Table 2. High tariffs levied on imported goods are associated with negative impacts on the volumes exported by exporting countries. For example a study on "Estimating the Constraints to Agricultural Trade of Developing Countries" conducted by Moïsé et al. (2013) found out that a reduction by 10 percent in the tariff trade restrictiveness have a potential, on average, to a 3.7 percent increase in agricultural exports.

Table 2. Regression results for oranges from South Africa to European countries

\begin{tabular}{llll}
\hline Variables & Coef. & t-value & $\mathrm{P}>\mathrm{t}$ \\
\hline lngdp & 0.2381833 & 1.81 & $0.073^{*}$ \\
lndist & -0.3057078 & -0.13 & 0.896 \\
$\ln$ exch & -0.8750899 & -3.60 & $0.000^{* * *}$ \\
$\operatorname{lnT}$ & 145.8166 & 0.78 & 0.436 \\
$\operatorname{lngdppc}$ & 1.124972 & 3.07 & $0.003^{* *}$ \\
cons & -10.13074 & -0.44 & 0.663 \\
\hline
\end{tabular}

Number of obs $=130$

Prob $>\mathrm{F}=0.0000$

R-squared $=0.2793$

Adj R-squared $=0.2503$

Note. Significance levels indicated by *** $(\mathrm{P}$ value $<0.01),{ }^{* *}(0.01<\mathrm{P}$ value $<0.05)$ and $*(0.05<\mathrm{Pv}$ alue $<$ $0.10)$. 


\subsection{Analysis of SA Orange Exports to Top Importing Asian Countries}

Many fast developing countries in this era are Asian countries. An increase in the demand of fruits in these countries has seen steep increase over the past decade. Such high demand can be associated with fast economic growth which leads to high incomes that further lead to consumption of high valuable foods which include fruits. Asian market has been gradually becoming a market destination of importance to SA orange exporters. Turning to regression results presented in Table 3 bellow, the estimated coefficients have expected signs and are statistically significant except distance which is statistically insignificant and has a positive sign. One of the reasons for distance to be statistically insignificant and positive sign might be due to a missing variable in the used equation, and that requires a further research beyond this paper. A 1 percent increase in the GDP of the analyzed top importing Asian countries tends to be associated with a $8 \%$ increase in the volumes of oranges being exported by South Africa and the estimated parameter is highly significant statistically at the P-value < 0.01 . Real exchange rate over the years studied is positively significant indicating that the declining of SA currency stimulates more exports to these Asian countries with stronger currencies than SA. A 1\% increase in real exchange rate tends to be associated with $0.2 \%$ increase in imports in these reviewed countries. This finding is in line with the explanation given by Bahar (1997) in the book titled "The Effects of Real Exchange Rate Volatility on Sectoral Investment: Empirical Evidence from Fixed and Flexible Exchange Rate Systems (Financial Sector of the American Economy)", that the real exchange rate coefficients are positively significant in the regressions, indicating that real exchange rate appreciations stimulate investment spending, in the case of this paper it means it becomes cheaper for the importing countries to procure more of SA oranges. On the other hand for each 1 percent increase in tariffs levied on SA oranges when exported tend to be associated with a fall of $4 \%$. Hope remains for SA orange exporters to increase the volumes of oranges exported to the Asian market as some of these countries have cut tariffs significantly over the past 7 years.

Table 3. Regression results for oranges from South Africa to top Asian importing countries

\begin{tabular}{llll}
\hline Variables & Coef. & t-value & $\mathrm{P}>\mathrm{t}$ \\
\hline lngdp & 0.7975052 & 7.64 & $0.000^{* * *}$ \\
lndist & 5.770885 & 1.84 & $0.070^{*}$ \\
lnexch & 0.0179553 & 0.15 & 0.885 \\
ortariff & -0.4000368 & -7.62 & $0.000^{* * *}$ \\
lngdppc & -0.2844416 & -1.52 & 0.132 \\
cons & -61.30618 & -2.05 & 0.043 \\
\hline & Number of obs $=91$ & & \\
& Prob $>$ F $=0.0000$ & & \\
& R-squared $=0.5993$ & & \\
\hline
\end{tabular}

Note. Significance levels indicated by $* * *(\mathrm{P}$ value $<0.01), * *(0.01<\mathrm{P}$ value $<0.05)$ and $*(0.05<\mathrm{P}$ value $<$ $0.10)$.

\section{Conclusion}

The analysis of this paper has been to determine factors encouraging and discouraging trade of South Africa's oranges to the top selected importing countries in Europe and Asia. Findings have shown that over the reviewed period, South Africa's orange exports to the European market have been consistence, while exports to Asian market started slow and gradually increased over the years. Gravity model findings also detailed the determinants which have encouraged and discouraged the volumes exported over the studied period. In both markets, Europe and Asia, GPD encourages volumes of oranges imported as both coefficients' in the regression results are positive significant. On the other hand, tariff parameter estimates have differed in the regression results of these two markets, European market yielded a positive sign coefficient while Asian market yielded a negative coefficient sign. The positive tariff coefficient in the regression results for European market can be associated with preferential tariff and most favored nation tariff agreement which South Africa has entered with these countries. As for the Asian market, the negative tariff coefficient in the regression results indicates that most of these countries are still in the process of phasing out the standing traffic at the borders. Real exchange rate presented a positive coefficient for Asian market and negative coefficient for European market. One of the reasons for such differences, the Asian market is developing very fast economical and has countries with very 
strong currencies compared to South African currency and that means this market can import large volumes of oranges from South Africa at low cost whereas European market has been faced with currency value decline over the years mostly the years reviewed in this paper. Even though there has been a detection of deterioration in the fit of the gravity equation used, the estimated parameters are general still significant and can provide a useful tool for assessing the potential gains from future trade agreements to be reached in.

Apart from the studied trade determinants in this paper, there remain other factors of importance in determining trade potentials of South Africa's orange exports to these markets such as non tariff measures. The non tariff measures can be justified under the auspices of issues such as health and standards. The above detected reason is an interesting task for further research.

\section{Acknowledgements}

This work was supported by the MOA Innovative Talents Project "Key Techniques of Main Agricultural Products Market Monitoring and Early Warning", founded by the Ministry of Agriculture, China; The MOA monitoring statistics Project on Agricultural and rural resources: "Agricultural Monitoring, Early Warning and Informatization", founded by Ministry of Agriculture, China and The CAAS Science and Technology Innovation Project: Innovation Team on Agricultural Production Management Digital Technology (number: CAAS-ASTIP-2015-AII-02), founded by Chinese Academy of Agricultural Sciences and Technology.

\section{References}

Bahar, E. (1997). The Effects of Real Exchange Rate Volatility on Sectoral Investment: Empirical Evidence from Fixed and Flexible Exchange Rate Systems (Financial Sector of the American Economy). Routledge.

Baldwin, R. E., \& Murray, T. (1977). MFN Tariff Reductions and Developing Country Trade Benefits under the GSP. The Economic Journal, 87(345). http://dx.doi.org/10.2307/2231831

Bergstrand, J. H. (1985). The gravity equation in international trade: Some microeconomics and empirical evidence. The Review of Economics and Statistics, 67, 474-481. http://dx.doi.org/10.2307/1925976

Buch, C. M., Kleinert, J., \& Toubal, F. (2004). The distance puzzle: On the interpretation of the distance coefficient in gravity equations. Economics Letters, 83, 293-298. http://dx.doi.org/10.1016/j.econlet.2003.10.022

DAFF (Department of Agriculture, Forestry and Fisheries). (2013). A profile of the South African citrus market value chain. Retrieved August 17, 2015, from http://www.daff.gov.za/docs/AMCP/CitrusMVCP 2010-11.pdf

Feenstra, R. C., Markusen, J. R., \& Rose, A. K. (2001). Using the gravity equation to differentiate among alternative theories of trade. Canadian Journal of Economics, 34(2), 430-447. http://dx.doi.org/10.1111/0008-4085.00082

Haddad, L. (2003). Redirecting the Diet Transition: What can food policy do? Development Policy Review, 5(6), 599-614. http://dx.doi.org/10.1111/j.1467-8659.2003.00226.x

Kapuya, T., Chinembiri, E. K., \& Kabala, M. W. (2014). Identifying strategic markets for South Africa's citrus exports. Agrekon: Agricultural Economics Research, Policy and Practice in Southern Africa, 53(1), 124-158. http://dx.doi.org/10.1080/03031853.2014.887908

Khuele, P. R. S., \& Darroch, M. A. G. (1997). Demand and supply factors in the export of South African fresh oranges to the United Kingdom: 1976-1993. Agrekon, 36(4).

Kristjánsdóttir, H. (2008). Exports under the Flicker of the Northern Lights. Economics Discussion Papers, No. 2008-17, Keil Institute for the World Economy. http://dx.doi.org/10.2139/ssrn.1723635

Maru, A. P. (2014). Forward Thinking ICT use in Agriculture and Agric Food Chains. Paper Prepared for presentation at the China Agricultural Outlook Conference, Beijing, China, April 19-21, 2015.

Melchior, A., Zheng, J., \& Johnsen, A. N. U. P. I. (2009). Trade barriers and export potential: Gravity estimates for Norway's exports. Paper written for the Ministry of Trade and Industry, Norway Oslo.

Ntombela, S., \& Moobi, M. (2013). South African fruit trade flow. Pretoria, South Africa: NAMC.

Popkin, B. M. (1993). Nutritional patterns and transition. Population and Development Review, 19(1), 138-157. http://dx.doi.org/10.2307/2938388

Pöyhönen, P. (1963). A Tentative Model for the Volume of Trade between Countries. Weltwirtschaftliches Archive, 90, 93-100. 
Reardon, T., Timmer, C. P., \& Berdegué, J. A. (2003). The rise of supermarkets in Latin America and Asia: Implications for international markets for fruits and vegetables. Global markets for high value food products. Agriculture Information Bulletin, USDA-ERS.

Tinbergen, J. (1962). Shaping the World Economy: Suggestions for an International Economic Policy. New York: Twentieth Century Fund. The first use of a gravity model to analyze international trade flows. Am. $J$. Agr. Econ., 46(1), 271-273. http://dx.doi.org/10.2307/1236502

\section{Copyrights}

Copyright for this article is retained by the author(s), with first publication rights granted to the journal.

This is an open-access article distributed under the terms and conditions of the Creative Commons Attribution license (http://creativecommons.org/licenses/by/3.0/). 